\title{
A Systematic Review of the Recent Quality of Life Studies in Adult Extremity Sarcoma Survivors
}

\author{
Melissa H. Tang, ${ }^{1,2}$ Donald J. W. Pan,,3 David J. Castle, ${ }^{2,4}$ and Peter F. M. Choong1,2 \\ ${ }^{1}$ Department of Orthopaedics, St Vincent's Hospital Melbourne, Level 3 Daly Wing, 35 Victoria Parade, Fitzroy, VIC 3065, Australia \\ ${ }^{2}$ Faculty of Medicine, Dentistry and Health Sciences, The University of Melbourne, VIC 3010, Australia \\ ${ }^{3}$ Engage 1 on 1 Psychology, 181 High Street, Northcote, VIC 3070, Australia \\ ${ }^{4}$ Department of Psychiatry, St Vincent's Hospital Melbourne, 41 Victoria Parade, Fitzroy, VIC 3065, Australia
}

Correspondence should be addressed to Melissa H. Tang, mel_tang2003@yahoo.com.au

Received 6 February 2012; Revised 6 May 2012; Accepted 15 May 2012

Academic Editor: Kristy Weber

Copyright (C) 2012 Melissa H. Tang et al. This is an open access article distributed under the Creative Commons Attribution License, which permits unrestricted use, distribution, and reproduction in any medium, provided the original work is properly cited.

\begin{abstract}
Background. Extremity sarcoma represents a heterogeneous group of rare cancers that carries a relatively high morbidity with regards to physical function. Quality of Life (QoL) as an outcome is an important consideration in this cohort. We aimed to identify the correlates of QoL in extremity sarcoma cohorts. Methods. A systematic review of the literature on extremity sarcoma in adults from five databases over the last ten years was undertaken. Results. Twelve articles were chosen and assessed for quality. Physical and social function of extremity sarcoma survivors is below that of the general population. Overall QoL scores of these patients are comparable to those of the general population. Studies that used more recently treated cohorts found that patients who had limb sparing surgery displayed superior functional outcomes over those that underwent amputations. Pain and perceiving that the cancer negatively influenced opportunities was associated with poor outcomes. Conclusion. The available literature regarding QoL in extremity sarcoma patients is heterogeneous in terms of aims and assessment tools. Results need to be interpreted in light of the improved management of extremity sarcoma in more recent patient cohorts.
\end{abstract}

\section{Introduction}

Extremity bone and soft tissue sarcoma represents a rare and heterogeneous group of bone and connective tissue cancers, which accounts for $0.2 \%$ and $0.5 \%$ of all cancers in Australia [1], respectively. Most musculoskeletal neoplasms occur within specific age ranges and have a predilection for specific sites. $60 \%$ of all sarcomas occur in people who are younger than 55 years old [2]. The arbitrary cutoff for the definition of adolescents and young adults (AYA) is not clearly defined in the literature; however, most studies take the limit of fifteen years old [3]. Adolescence represents a period of developmental transitions, characterised by cognitive, biological, and socioeconomic challenges [4]. Health problems such as cancer, in this age group, are uncommon as cancer is predominantly a disease of the older population. Considering cancer in all age groups, sarcoma is rare. In Australia, soft tissue sarcoma was the 9th most common cancer, accounting for 3.2\% (279 cases) of all cancers in AYA between 2003 and 2007. During this timeframe, bone cancer was the second most common cause of cancer death (107 deaths, $10.5 \%$ of all cancer deaths) whilst soft tissue cancer was the seventh most common cause of cancer death (60 deaths, 5.9\% of all cancer deaths) in AYAs. The mortality and morbidity associated with sarcoma is high. Paediatric cancer centres and adult cancer centres may not be adequately equipped to manage the unique demands of cancer patients in this age group [5]. In Victoria, we manage patients who are older than fifteen years old in an adult cancer facility.

Advancements in medical imaging technology, greater understanding of the biology of tumours, development of powerful chemotherapeutic regimens, improvements in technique, and availability of reliable reconstruction options have revolutionised the management of sarcoma and resulted in improved mortality and morbidity of sarcoma survivors. 
Neoadjuvant therapy has made it possible for some patients with previously unresectable tumours to undergo limb sparing surgery through tumour regression [6]. It is recognised that there is no difference between limb sparing surgery and amputation in terms of survival or local recurrence, provided adequate margins are obtained and, therefore, limb sparing surgery is the gold-standard surgical option for a patient with extremity sarcoma, especially for distal lower limb tumours [7-10]. Research using more recently treated cohorts found that physical function was superior following limb sparing surgery compared to amputation $[8,11]$.

It is recognised that the level of physical functioning of sarcoma survivors is below that of the general population. Despite that, the QoL of survivors appears to remain comparable to that of the general population.

Health-related quality of life (QoL) is a multidimensional construct that considers the impact of an individual's health status on his or her life and opportunities. It is subjective and may be modified by impairments, functional status, perceptions, and social opportunities and may be influenced by disease, injury, treatment, and policy [12, 13]. Given that QoL has to be considered in the context of the individual's environment; QoL studies should be interpreted in the context of the timeframe it was performed. QoL studies that were performed more than a decade ago may represent a different clinical and social environment compared to more recently performed studies. Various studies have reported trends towards improved outcomes with time [14-16]. Apart from improved chemotherapeutic regiments, these authors have postulated that this is due to the formation of multidisciplinary sarcoma groups. In Victoria, the Victorian Cooperative Oncology Group, Sarcoma Section was established in 2006. We have chosen an arbitrary timeframe of QoL studies performed in the last decade to represent studies that are more relevant to the current clinical and sociopolitical environment.

Measures of QoL are divided into three main domains: physical function, mental health, and social well being [13].

To explore the issue of QoL in extremity sarcoma survivors that is relevant to our practice, we performed a systematic review of journal articles published in the last decade on QoL in sarcoma in studies that assessed patients who were fifteen years or older. The key question guiding OUR review was the following: what are the modulators of QoL in extremity sarcoma? The aims of our study was to (1) evaluate the quality of the current literature on QoL in extremity sarcoma, (2) identify the tools used to assess QoL in extremity sarcoma, (3) evaluate the physical function, mental health and overall QoL of extremity sarcoma survivors compared to the general population, (4) compare the functional and QoL outcomes between limb sparing surgery and amputation, and (5) identify the factors that are postulated to influence QoL outcomes (determinants of QoL).

\section{Search Strategy and Criteria}

We performed a systematic review of the current literature from five databases (PubMed, CINAHL, Psychinfo, Medline, and Melbourne University Library Catalogue) with the following keywords: sarcoma AND "quality of life".

Exclusions included: articles published before 2001, haematological malignancies, Kaposi sarcoma, retinoblastoma, paediatric sarcomas (mean age at diagnosis (MAD) $<15$ years old, or mean age at surgery $<15$ years old if MAD not provided), QoL studies on heterogeneous, general cancer population, QoL of other noncancer populations in general, basic sciences research or animal model studies, and nonextremity sarcomas. We also excluded case reports and articles for which full text was not available as well as articles in which physical function alone was assessed and other domains of QoL were not assessed. Non-English articles with English translations were included.

\section{Results}

A total of 3713 articles were found. The reviewers (M. H. Tang and D. J. W. Pan) independently applied exclusion criteria and removed duplicates through reading titles and abstracts. Nine articles were found that met inclusion criteria. Other relevant articles were tracked through systematic reviews and a further three studies were included (total twelve).

3.1. Results: Quality Assessment. We utilized the NewcastleOttawa Quality Assessment Scale (NOS) for cohort studies to assess the quality of the articles [28]. The NOS awards stars for three categories: "Selection", "Comparability", and "Outcome", each divided into further subcategories. Each study can be awarded a maximum of one star for each subcategory whilst Comparability can be awarded a maximum of two stars as summarized by Table 1 .

\subsubsection{Selection}

(i) Representativeness: we awarded one star if the study clearly described the aims of the study and set about to clearly achieve the aims with the appropriate cohort chosen.

(ii) Selection of the nonexposed cohort: we awarded one star if the comparative group, for example, amputees versus limb sparing surgery, was derived from the same community as the entire extremity sarcoma group.

(iii) Ascertainment of exposure: we awarded one star if the authors noted confirmation of the diagnosis of extremity sarcoma via medical records.

(iv) Demonstration that outcome of interest were not present at the start of the study: we awarded one star if baseline function and QoL was noted.

\subsubsection{Comparability}

(i) We awarded one star if the study controlled for era of management. We defined this to be the entire cohort operated on in a ten-year timeframe. A further star 
TABLE 1: Quality assessment of selected studies.

\begin{tabular}{|c|c|c|c|c|}
\hline \multirow{2}{*}{ Reference } & \multirow{2}{*}{ Date of publication } & \multicolumn{3}{|c|}{ NOS rating } \\
\hline & & Selection & Comparability & Outcome \\
\hline Eiser [17] & 2001 & $* * *$ & $*$ & $* * *$ \\
\hline Davis et al. [18] & 2002 & $* * * *$ & $* *$ & $* * *$ \\
\hline Refaat et al. [19] & 2002 & $* *$ & $*$ & $* * *$ \\
\hline Rödl et al. [20] & 2002 & $* * *$ & & $* *$ \\
\hline Zahlten-Hinguranage et al. [21] & 2004 & $* *$ & $*$ & $* *$ \\
\hline Pardasaney et al. [11] & 2006 & $* * *$ & $*$ & $*$ \\
\hline Schreiber et al. [22] & 2006 & $* * * *$ & $* *$ & $* * *$ \\
\hline Thijssens et al. [23] & 2006 & $* * *$ & $*$ & $* * *$ \\
\hline Weiner et al. [24] & 2006 & $* * *$ & $*$ & $* * *$ \\
\hline Aksnes et al. [25] & 2008 & $* * *$ & $*$ & $* * *$ \\
\hline Davidge et al. [26] & 2009 & $* * *$ & $* *$ & $* * *$ \\
\hline Paredes et al. [27] & 2011 & $* * *$ & $*$ & $* *$ \\
\hline
\end{tabular}

was awarded if the study controlled for anatomical location, type of sarcoma, or grade of sarcoma.

\subsubsection{Outcome}

(i) Assessment of outcome: we awarded one star if the assessment tool was a well-known and widely used validated tool, for example, SF-36, EORTC QLQ C-30, TESS, MSTS87, and MSTS93 (abbreviations under Table 2).

(ii) Duration of followup: we awarded one star if the mean followup was one year or longer.

(iii) Adequacy of followup of cohorts: We awarded one star if there was more than $70 \%$ response rate OR if the nonresponders were statistically analysed to account for sampling bias.

3.1.4. Sample Size. From the selected articles, two studies had a participant size of more than 200 [11, 19], six had between 100 and 200 participants [18, 21, 22, 25-27], none had between 50 and 100 participants and four had between 20 and 50 responders $[17,20,23,24]$.

3.1.5. Study Design. Of all the studies, nine were retrospective studies $[11,17,19-21,23,25-27]$, whilst two were longitudinal studies $[18,22]$.

3.1.6. Cohort-Anatomical Location. Six studies looked at a specific anatomical location. Out of these, four looked at tumours involving the lower limb $[11,17,19,21]$, whilst one study looked at tumours around the knee [20].

3.1.7. Cohort-Histological Subtypes. Some studies looked at specific types of bone or soft tissue sarcoma subtypes. For example, two studies examined osteosarcoma and Ewing's sarcoma patients $[17,25]$. Some studies studied a heterogeneous cohort of bone sarcoma patients [20] or soft tissue sarcoma patients $[18,22,23,26]$.
3.1.8. Aims. Two studies were performed with a specified aim of descriptive statistics purposes. They described the functional, QoL, and/or oncological outcomes within their defined cohort [25, 27]. Most studies, however, included a description of their cohort when measuring their outcomes.

Two studies were performed to compare QoL between patients that had undergone limb sparing surgery and those that had an amputation [19, 21]. Eiser et al. [17] included a third group - those that had an amputation following failed limb sparing surgery. Three groups compared limb sparing and amputation according to resection level $[11,19,25]$.

One study was performed with a sole aim to identify the prevalence of depression and anxiety throughout different phases of the disease [27]. Five studies stated prevalence of psychological distress in their cohort [11, 19, 23, 24, 27].

Five studies compared their findings against published figures for the reference normal population $[17,18,20,23$, 25].

Six studies attempted to identify determinants of QoL $[17,21-23,25,26]$. For example, Schreiber et al. [22] aimed to evaluate how functional disabilities impacted on QoL, whilst Davidge et al. [26] attempted to evaluate how preoperative expectations impacted upon postoperative function and QoL. Thijssens et al. [23] looked at determinants of QoL and posttraumatic stress symptoms in their cohort of locally advanced soft tissue sarcoma patients who had all undergone neoadjuvant chemotherapy.

One study compared QoL and functional outcomes between patients who had neoadjuvant radiation therapy prior to limb sparing surgery and those that had adjuvant radiation therapy following limb sparing surgery [18].

3.1.9. Tools Used. Table 2 summarizes the tools used by each study. The most widely used tools were the TESS, MSTS87, and SF-36. Specific groups tended to use similar tools. For example, the German authors tended to use the FLZ [21], whilst the Canadian group tended to include TESS, and if MSTS was used, that tended to use the 1987 version [18, 22, 26]. The Americans used their own computer-generated tool $[11,19]$. 
TABLE 2: Tools used in the assessment of QoL in sarcoma patients.

\begin{tabular}{|c|c|c|}
\hline Tool & Number of studies & References \\
\hline MSTS87 & 3 & $\begin{array}{l}\text { Schreiber et al. } 2006 \text { [22], Davidge et al. } 2009 \text { [26], Davis et al. } 2002 \\
\text { [18] }\end{array}$ \\
\hline MSTS93 & 2 & Zahlten-Hinguranage et al. 2004 [21], Aksnes et al. 2008 [25] \\
\hline TESS & 4 & $\begin{array}{l}\text { Eiser et al. } 2001 \text { [17], Schreiber et al. } 2006 \text { [22], Davidge et al. } 2009 \\
\text { [26], Davis et al. } 2002 \text { [18] }\end{array}$ \\
\hline SF-36 & 4 & $\begin{array}{l}\text { Eiser et al. } 2001 \text { [17], Aksnes et al. } 2008 \text { [25], Thijssens et al. } 2006 \text { [23] } \\
\text { (used Dutch version of RAND-36), Davis et al. } 2002 \text { [18] }\end{array}$ \\
\hline EORTC QLQ C-30 & 2 & Zahlten-Hinguranage et al. 2004 [21], Rödl et al. 2002 [20] \\
\hline Semistructured interviews & 2 & Weiner et al. 2006 [24], Eiser et al. 2001 [17] \\
\hline BSI & 1 & Weiner et al. $2006[24]$ \\
\hline IES & 2 & Weiner et al. 2006 [24], Thijssens et al. 2006 [23] \\
\hline Body image instrument & 1 & Eiser et al. $2001[17]$ \\
\hline Computer generated 5 page 87 question tool & 2 & Refaat et al. 2002 [19], Pardasaney et al. 2006 [11] \\
\hline FLZ & 1 & Zahlten-Hinguranage et al. 2004 [21] \\
\hline HADS & 1 & Paredes et al. $2010[27]$ \\
\hline RNL & 2 & Schreiber et al. 2006 [22], Davidge et al. 2009 [26] \\
\hline EQVAS & 2 & Schreiber et al. 2006 [22], Davidge et al. 2009 [26] \\
\hline LOT & 2 & Schreiber et al. 2006 [22], Davidge et al. 2009 [26] \\
\hline Fatigue questionnaire & 1 & Aksnes et al. 2008 [25] \\
\hline Single item, questions & N/A & $\begin{array}{l}\text { Aksnes et al. } 2008 \text { [25]: pain, stiffness, influence of sarcoma on choice } \\
\text { of career and level attained, and activity participation (hours per } \\
\text { week) differentiated into low and high energy demand activity type, } \\
\text { Davidge et al. } 2009 \text { [26]: socioeconomic questions } \\
\text { Thijssens et al. } 2006 \text { [23]: perception of involvement in decision } \\
\text { making and satisfaction based on a 5-point Likert scale }\end{array}$ \\
\hline $\begin{array}{l}\text { Outcome expectation self-report } \\
\text { questionnaire }\end{array}$ & 1 & $\begin{array}{l}\text { Davidge et al. } 2009 \text { [26]: length of hospitalization, complications, } \\
\text { difficulty with daily activities }\end{array}$ \\
\hline
\end{tabular}

MSTS87: Musculoskeletal Tumour Society Score 1987 version; MSTS93: Musculoskeletal Tumour Society Score 1993 version; TESS: Toronto Extremity Salvage Score; SF-36: Short Form 36 Health Survey; EORTC QLQ C-30: European Organisation for Research and Treatment of Cancer Quality of Life Questionnaire Core Module 30; BSI: Brief Symptom Inventory; IES: Impact of Event Scale; FLZ: Freiburger Life-Contentment List; HADS: The Hospital Anxiety and Depression Scale; RNL: Reintegration to Normal Living Scale; EQ-VAS: EuroQoL Visual Analogue Scale; LOT: Life Orientation Test.

3.2. Study Design and Measure. Study design and measures used were heterogeneous as summarized in Table 3.

\subsection{Results: Findings}

3.3.1. Comparing the Sarcoma Population with the General Population. Studies utilizing global QoL assessment tools found that physical and social function for sarcoma survivors was significantly lower than that of the general population when measured with the SF-36 [17, 18, 23]. In these studies, emotional functioning and mental health scores were not significantly different between sarcoma survivors and the general population.

3.3.2. Comparing Type of Surgeries: Limb Sparing Surgery versus Amputation. Six studies were performed to compare QoL and physical function between limb sparing surgery and amputation $[11,17,19,21,23,25]$. The studies are summarised in Table 4.

Using an arbitrary cutoff of 1990, studies that used cohorts treated after 1990 were able to show that limb sparing surgery displayed significantly better functional outcomes compared to amputation $[17,21,23,25]$. Studies that used cohorts treated before 1990 failed to show a significant difference $[11,19]$.

3.3.3. Identification of Determinants of Quality of Life. Despite poor physical function, sarcoma survivors reported high scores on QoL assessments, with scores comparable to that of the general population $[17,21,25]$. Therefore, physical function may not be the biggest discriminant of QoL in extremity sarcoma survivors. Other determinants may contribute to satisfactory QoL as summarized in Table 5. Various studies attempted to examine the different determinants of well being, which may evolve in the face of cancer. In a study of long-term survivors of sarcoma, 94\% of participants stated that they felt that the cancer had made them a "better person" [24].

Specific Determinants of QoL. Four studies evaluated the ability of chosen variables to predict QoL. 
TABLe 3: Summary of study design.

\begin{tabular}{|c|c|c|c|}
\hline Reference & Study design/sample & Measures used & $\begin{array}{c}\text { Timeframe of } \\
\text { treatment }\end{array}$ \\
\hline Eiser 2001 [17] & $\begin{array}{l}\text { Retrospective cross-sectional study of } \\
\text { patients with osteosarcoma and } \\
\text { Ewing's sarcoma of the lower limb } \\
N=37 \\
\text { Median age of diagnosis }=19(7-37) \\
\text { years } \\
\text { Median time since diagnosis }=10 \\
(2-33) \text { years }\end{array}$ & $\begin{array}{l}\text { SF-36 } \\
\text { Body image instrument } \\
\text { TESS: daily competence } \\
\text { Use of analgesia and gait aids } \\
\text { Semistructured interview }\end{array}$ & 1977-1995 \\
\hline Davis et al. 2002 [18] & $\begin{array}{l}\text { Prospective randomized study of } \\
\text { nonmetastatic extremity STS patients } \\
\text { Tumour size was dichotomized at } \\
10 \mathrm{~cm} \text {, then randomized to PreRT } \\
\left(\begin{array}{l}n=88) \text { or PostRT }(n=94) \\
N=182 \\
\mathrm{MAD}=54.7(18.8-93.8) \text { years }\end{array}\right.\end{array}$ & $\begin{array}{l}\text { MSTS87 } \\
\text { TESS: primary measure: } 10 \text {-point } \\
\text { difference considered significant SF-36 } \\
\text { Timepoints: baseline (at } \\
\text { randomisation), } 6 \text { weeks, } 3,6,12 \text {, and } \\
24 \text { months after surgery }\end{array}$ & 1994-1997 \\
\hline Refaat et al. 2002 [19] & $\begin{array}{l}\text { Retrospective study on patients with } \\
\text { lower limb sarcoma } \\
N=408 ; \text { Amp } n=66 \text {, LSS } n=342 \\
\text { MAD }=47.5 \text { years }\end{array}$ & Computer generated questionnaire & $1972-1987$ \\
\hline Rödl et al. 2002 [20] & $\begin{array}{l}\text { Patients with high grade malignant } \\
\text { bone tumours of distal femur that } \\
\text { underwent rotationplasty } \\
N=22 \\
\text { Mean followup }=12(10-18) \text { years } \\
\text { Median age at time of study }=28 \\
(18-49) \text { years }\end{array}$ & $\begin{array}{l}\text { EORTC QLQ C-30FLZ } \\
\text { Education level }\end{array}$ & \\
\hline $\begin{array}{l}\text { Zahlten-Hinguranage } \\
\text { et al. } 2004[21]\end{array}$ & $\begin{array}{l}\text { Retrospective, cross-sectional study of } \\
\text { patients with lower limb (excluding } \\
\text { foot and ankle) sarcoma } \\
N=124(\text { LSS } n=102 ; \text { Amp } n=22) \\
\text { Mean age at assessment = } 35(14-76) \\
\text { years } \\
\text { Mean time from surgery = } 46(6-250) \\
\text { months }\end{array}$ & $\begin{array}{l}\text { EORTC QLQ-C30 } \\
\text { MSTS93 } \\
\text { FLZ }\end{array}$ & $1980-2000$ \\
\hline $\begin{array}{l}\text { Pardasaney et al. } 2006 \\
{[11]}\end{array}$ & $\begin{array}{l}\text { Retrospective comparative study on } \\
\text { patients with sarcoma of the lower } \\
\text { limb with at least } 2 \text {-year followup } \\
N=408 \text { (Amp } n=65, \text { LSS } n=343) \\
\text { Mean age at surgery }=40.36(2-86) \\
\text { years } \\
\text { Mean time from treatment }=8.91 \\
(2-27) \text { years. }\end{array}$ & $\begin{array}{l}\text { Computer generated quality of life } \\
\text { questionnaire }\end{array}$ & \\
\hline $\begin{array}{l}\text { Schreiber et al. } 2006 \\
{[22]}\end{array}$ & $\begin{array}{l}\text { Longitudinal study on nonmetastatic } \\
\text { STS patients who had LSS } \\
N=100 \\
\text { MAD = } 55(18-86) \text { years }\end{array}$ & $\begin{array}{l}\text { MSTS87 } \\
\text { TESS } \\
\text { RNL } \\
\text { EQ-VAS } \\
\text { LOT } \\
2 \text { timepoints: preoperatively and } 1 \text { year } \\
\text { postoperatively }\end{array}$ & $2001-2003$ \\
\hline $\begin{array}{l}\text { Thijssens et al. } 2006 \\
\text { [23] }\end{array}$ & $\begin{array}{l}\text { Retrospective cross-sectional study on } \\
\text { survivors of locally advanced, } \\
\text { nonmetastatic STS, who underwent } \\
\text { isolated limb perfusion, with } \\
\text { intentional delayed LSS } \\
N=39 \text { (LSS } n=30 \text {, Amp } n=9) \\
\text { Median age at perfusion }=49(14-72) \\
\text { years } \\
\text { Median time since perfusion }=7 \\
\text { (1-13) years }\end{array}$ & $\begin{array}{l}\text { IES } \\
\text { SF-36 } \\
\text { Perception of involvement in decision } \\
\text { Treatment satisfaction: 5-point Likert } \\
\text { scale }\end{array}$ & $1991-2003$ \\
\hline
\end{tabular}


TABLE 3: Continued.

\begin{tabular}{|c|c|c|c|}
\hline Reference & Study design/sample & Measures used & $\begin{array}{c}\text { Timeframe of } \\
\text { treatment }\end{array}$ \\
\hline Weiner et al. 2006 [24] & $\begin{array}{l}\text { Cross-sectional study of long-term } \\
\text { survivors of sarcoma } \\
N=34 \\
\text { MAD }=16 \text { (7-34 years) } \\
\text { Mean age at study }=34(17-54 \text { years }) \\
\text { Mean time from diagnosis }=18 \text { (4-33 } \\
\text { years) }\end{array}$ & $\begin{array}{l}\text { Semi-structured interview } \\
\text { BSI (intensity of psychological } \\
\text { distress) } \\
\text { IES }\end{array}$ & \\
\hline Aksnes et al. 2008 [25] & $\begin{array}{l}\text { Retrospective study on patients with } \\
\text { osteosarcoma or Ewing's sarcoma } \\
N=118(\text { LSS } n=67, \text { Amp } n=51) \\
\text { MAD }=18(2-44) \text { years } \\
\text { Mean time since diagnosis }=13(6-22) \\
\text { years }\end{array}$ & $\begin{array}{l}\text { SF-36 } \\
\text { TESS } \\
\text { MSTS93 }\end{array}$ & $1982-2000$ \\
\hline Davidge et al. 2009 [26] & $\begin{array}{l}\text { Retrospective cohort study on adult } \\
\text { patients with nonmetastatic extremity } \\
\text { STS who underwent LSS } \\
\text { Outcome measures assessed at two } \\
\text { time points: preoperatively and } 12 \\
\text { months postoperatively } \\
\text { Categories collapsed to allow for } \\
\text { sufficient powering } \\
N=157\end{array}$ & $\begin{array}{l}\text { Outcome expectation questionnaire } \\
\text { MSTS87 } \\
\text { TESS } \\
\text { RNL } \\
\text { EQ5D-VAS } \\
\text { LOT }\end{array}$ & 2001-2005 \\
\hline Paredes et al. 2011 [27] & $\begin{array}{l}\text { Cross-sectional descriptive study on } \\
\text { sarcoma patients in different phases of } \\
\text { disease } \\
N=142 \\
\text { Dx } n=42 \text {, mean time from diagnosis } \\
=4.27 \text { months; } \mathrm{Rx} n=37 \text {, mean time } \\
\text { from diagnosis }=10.94 \text { months, mean } \\
\text { time from treatment }=9.34 \text { months; } \\
\text { Fx } n=63 \text {, mean time since } \\
\text { completion of treatment }=52.93 \\
\text { months } \\
\text { MAD }=48.32 \text { years }\end{array}$ & $\begin{array}{l}\text { HADS } \\
\text { Demographic and clinical } \\
\text { questionnaire }\end{array}$ & \\
\hline
\end{tabular}

STS: soft tissue sarcoma; PreRT: neoadjuvant radiation therapy; PostRT: adjuvant radiation therapy; MAD: mean age of diagnosis; Amp: amputation; LSS: limb sparing surgery; Dx: diagnosis phase; Rx: treatment phase (1st treatment, whether it was chemotherapy, radiation therapy, and/or surgery counted as index timepoint); Fx: followup phase.

TABLE 4: Summary of studies comparing limb sparing surgery with amputation.

\begin{tabular}{|c|c|c|c|}
\hline Author & $\begin{array}{l}\text { Timeframe that } \\
\text { cohorts were } \\
\text { treated }\end{array}$ & Conclusions regarding QoL & Conclusions regarding physical function \\
\hline Eiser 2001 [17] & 1977-1995 & No significant difference & LSS superior over amputation \\
\hline Refaat et al. 2002 [19] & $1972-1987$ & No significant difference & No significant difference \\
\hline $\begin{array}{l}\text { Zahlten-Hinguranage } \\
\text { et al. } 2004 \text { [21] }\end{array}$ & $1980-2000$ & No significant difference & LSS superior over amputation \\
\hline $\begin{array}{l}\text { Pardasaney et al. } 2006 \\
\text { [11] }\end{array}$ & - & $\begin{array}{l}\text { No significant difference except for above knee } \\
\text { amputation, which had inferior outcomes }\end{array}$ & $\begin{array}{l}\text { No significant difference except for above knee } \\
\text { amputation, which had inferior outcomes }\end{array}$ \\
\hline $\begin{array}{l}\text { Thijssens et al. } 2006 \\
\text { [23] }\end{array}$ & $1991-2003$ & No significant difference & LSS superior over amputation \\
\hline Aksnes et al. 2008 [25] & $1982-2000$ & No significant difference & LSS superior over amputation \\
\hline
\end{tabular}


TABLE 5: Studies that correlated variables with overall QoL.

\begin{tabular}{ll}
\hline Reference & Finding \\
\hline $\begin{array}{l}\text { Eiser et al. 2001 } \\
{[17]}\end{array}$ & $\begin{array}{l}\text { Low TESS scores and poor body image predicts } \\
\text { poor QoL }\end{array}$ \\
$\begin{array}{l}\text { Schreiber et al. } \\
\text { 2006 [22] }\end{array}$ & Complications of surgery associated with poor \\
$\begin{array}{l}\text { Davidge et al. } \\
\text { 2009 [26] }\end{array}$ & Uncertain expectations associated with poor \\
Thijssens et al. & Pain associated with poor QoL \\
2006 [23] & \\
\hline
\end{tabular}

Other factors involved in one or more aspects of QoL were studied and described below.

(i) Sport Participation Following Surgery. Only about half the population studied by Pardasaney et al. [11] reported being active in sport, whilst Refaat et al. [19] found that only one patient participated in a contact-type sport. Both studies did not correlate sport participation with QoL. Aksnes et al. [25] found that physical activity per se was not significantly associated with poor functional outcomes; however, it was not assessed if a change in baseline physical activity was significant.

(ii) Employment. Employment was studied in four studies as shown in Table 6 . The most consistent finding in these studies is that in a subset of patients, cancer negatively influenced work or school and this was significantly associated with poor outcomes.

(iii) Personality. Three studies attempted to study some facet of personality as shown in Table 7. Being optimistic was consistently associated with good function outcomes.

(v) Psychological Distress. Mental health is one of the domains of QoL and is therefore assessed by QoL assessment tools. Table 8 summarises the findings regarding mental health by studies that used QoL tools. A further three studies assessed mental health directly by utilizing tools designed specifically for the detection of psychological distress. The results of these three studies are summarized in Table 9. In general, studies that used QoL tools found that mental health scores were comparable to that of the general population. However, studies that used other measures of psychological distress revealed that a significant proportion of the cohorts studied displayed significant psychological distress.

(vi) Tumour Characteristics. Davis et al. [18] found that patients who had a larger resection specimen and those who had motor nerve sacrifice did proportionately worse than baseline in terms of function. Recurrence and highergrade tumour at diagnosis were associated with poorer psychological and functional outcomes [23, 27]. Pain also significantly correlated with poor outcomes [25] and conversely, experiences that involved little pain were associated with good outcomes [23]. A summary of the findings form the selected studies is shown in Table 10.

\section{Discussion}

We performed a systematic review of twelve recently published articles that looked at QoL in grown-up patients with extremity sarcoma. We chose a cut-off age of fifteen years old, as this is the cutoff in Victorian hospitals for patients to be treated in an adult facility.

The available literature regarding QoL in extremity sarcoma patients is heterogeneous in terms of aims and assessment tools. The most widely used tools were the TESS and MSTS87 for physical function assessment and the SF-36 for global QoL assessment.

Our review confirmed that physical functioning, pain, and social functioning of extremity sarcoma survivors are significantly worse than the general population $[17,18,23]$.

Despite poorer function, overall QoL appears to be comparable to that of the general population. In a study of long-term survivors of sarcoma, $94 \%$ of participants stated that they felt that the cancer had made them a "better person" [24]. We were interested in the mechanism underlying the process of evolving and building resilience to adversity. The concept of "response shift" has been described by Sprangers and Schwartz to describe an evolution of internal standards, values, and conceptualisations in the face of disability such as that produced by cancer that influences one's self-perception of QoL [29]. The concept of "response shift" has been documented as a coping strategy in the general cancer literature. Hence, it is possible that survivors of extremity sarcoma adapt to their physical limitations and "grow" from their experiences with cancer; physical function is less important than other factors, such as other psychosocial variables as described above, in determining their QoL.

Regarding the mental health component of QoL, there is a mismatch in findings. Studies that use QoL assessment tools have found that emotional health domains are similar between sarcoma survivors and the general population. However, when studies used tools designed to detect psychological distress, the prevalence of distress in the cohorts ranged from $13.7 \%$ to $30.8 \%$ for depression and $11.8 \%$ to $29.2 \%$ for anxiety and $12 \%$ for PTSD.

In the Australian wider community, the prevalence of anxiety disorders is reported to be $14.4 \%$, of which the prevalence of PTSD is reported to be $6.4 \%$. The reported prevalence of depression in the general population is $6.2 \%$ [30].

Sarcoma can affect not only the life but also the livelihood of those it afflicts. Job security and the ability to perform work tasks may be impaired. The time required for management and recuperation, with imposed or consequent restrictions may lead to loss of ability to contribute to the workforce. The ability to work has personal economic, psychological, and community benefits. Weiner et al. [24] found that survivors of sarcoma who were unemployed were more likely to display psychological distress compared to those who were employed. Studies that looked at 
TABLE 6: Summary of employment characteristics.

\begin{tabular}{|c|c|c|c|}
\hline Reference & $\begin{array}{l}\text { Correlation of } \\
\text { unemployment with } \\
\text { outcomes }\end{array}$ & Unemployment rate & Further findings \\
\hline $\begin{array}{l}\text { Aksnes et al. } \\
2008[25]\end{array}$ & $\begin{array}{l}\text { Unemployment not } \\
\text { significantly associated with } \\
\text { poor functional outcomes }\end{array}$ & $\begin{array}{l}\text { (i) } 11 \% \text { of cohort unemployed } \\
\text { (ii) } 50 \% \text { of cohort reported that } \\
\text { cancer had negatively influenced } \\
\text { employment or educational choices }\end{array}$ & $\begin{array}{l}\text { (i) "Employment and education } \\
\text { opportunities negatively influenced by } \\
\text { cancer" significantly associated with } \\
\text { poor functional and QoL outcomes } \\
\text { (ii) Less than one-third of cohort } \\
\text { involved in physically demanding job }\end{array}$ \\
\hline $\begin{array}{l}\text { Pardasaney et al. } \\
2006 \text { [11] }\end{array}$ & Not assessed & $\begin{array}{l}\text { (i) Patients with below-knee } \\
\text { tumours: } 47.4 \% \text { amputees and } \\
23.3 \% \text { LSS patients unemployed } \\
\text { (ii) Patients with above knee } \\
\text { tumours: } 42.9 \% \text { of amputees and } \\
33.6 \% \text { of LSS patients unemployed }\end{array}$ & \\
\hline $\begin{array}{l}\text { Thijssens et al. } \\
2006[23]\end{array}$ & Not assessed & $\begin{array}{l}11.1 \% \text { of patients of working age } \\
\text { were unemployed }\end{array}$ & \\
\hline $\begin{array}{l}\text { Weiner et al. } \\
2006[24]\end{array}$ & $\begin{array}{l}\text { Unemployment } \\
\text { significantly associated } \\
\text { with psychological distress }\end{array}$ & $\begin{array}{l}\text { (i) } 35 \% \text { of cohort unemployed } \\
\text { (ii) } 24 \% \text { of cohort reported having } \\
\text { trouble with keeping up job or } \\
\text { school requirements }\end{array}$ & $\begin{array}{l}\text { "Difficulty with keeping up } \\
\text { requirements" significantly associated } \\
\text { with psychological distress }\end{array}$ \\
\hline
\end{tabular}

TABLE 7: Summary of personality characteristics.

\begin{tabular}{lll}
\hline Reference & Personality proxy measure & Correlation with outcomes \\
$\begin{array}{l}\text { Schreiber et al. } \\
2006[22]\end{array}$ & Optimism (LOT) & $\begin{array}{l}\text { Optimism significantly negatively correlated with poor physical function but no } \\
\text { significant association found with QoL }\end{array}$ \\
\hline $\begin{array}{l}\text { Thijssens et al. } \\
2006[23]\end{array}$ & $\begin{array}{l}\text { (i) Locus of control } \\
\text { (ii) Satisfaction with treatment }\end{array}$ & $\begin{array}{l}\text { (i) Perception of having less involvement in decision making process for } \\
\text { treatment" significantly associated with psychological distress } \\
\text { (ii) Patients who had outcomes consonant with preoperative expectations reported } \\
\text { more satisfaction postoperatively } \\
\text { (iii) Dissatisfaction with treatment was associated with psychological distress }\end{array}$ \\
\hline $\begin{array}{l}\text { Davidge et al. } \\
2009[26]\end{array}$ & $\begin{array}{l}\text { (i) Optimism (LOT) } \\
\text { (ii) Expectations of outcome }\end{array}$ & $\begin{array}{l}\text { (i) Optimism predictive of good functional and QoL outcomes } \\
\text { (ii) Pessimism associated with having uncertain expectations regarding recovery } \\
\text { following surgery }\end{array}$ \\
\hline
\end{tabular}

TABLE 8: Summary of mental health in extremity sarcoma patients-a reflection from QoL tools.

\begin{tabular}{|c|c|c|}
\hline Reference & QoL tool & Results \\
\hline Eiser et al. 2001 [17] & SF-36 & Mental health subscale comparable to general population \\
\hline Davis et al. 2002 [18] & SF-36 & $\begin{array}{l}\text { Mental health subscale comparable to general population but role } \\
\text { emotional lower than general population }\end{array}$ \\
\hline Refaat et al. 2002 [19] & Self-reported depression or anxiety & Prevalence in cohort of depression (17-26\%), anxiety $(22-26 \%)$ \\
\hline Rödl et al. 2002 [20] & EORTC QLQ C-30 & Mental health subscale comparable to general population \\
\hline $\begin{array}{l}\text { Zahlten-Hinguranage } \\
\text { et al. } 2004[21]\end{array}$ & EORTC QLQ C-30 & Not displayed \\
\hline $\begin{array}{l}\text { Pardasaney et al. } \\
2006[11]\end{array}$ & Self-reported depression or anxiety & $\begin{array}{l}\text { Patients who had above knee amputations were at an increased risk of } \\
\text { developing anxiety; otherwise, comparable to general population; } \\
\text { prevalence in LSS: depression }(30.8 \%) \text {, anxiety }(29.2 \%) \text {; prevalence in } \\
\text { amputation cohort: depression }(17.6 \%) \text {, anxiety }(11.8 \%)\end{array}$ \\
\hline $\begin{array}{l}\text { Aksnes et al. } 2006 \\
{[14]}\end{array}$ & SF-36 & $\begin{array}{l}\text { Poor functional subscales significantly correlated with poor emotional role } \\
\text { functioning }\end{array}$ \\
\hline
\end{tabular}


TABLE 9: Summary of mental health in extremity sarcoma patients—a reflection from IES, BSI (GSI), and HADS.

\begin{tabular}{lcl}
\hline Reference & Tool & Results \\
\hline $\begin{array}{l}\text { Thijssens et al. } \\
2006[23]\end{array}$ & IES & $\begin{array}{l}\text { Prevalence of PTSD in cohort: 12.2\%; RAND-36 } \\
\text { emotional subscale scores were comparable to reference } \\
\text { population }\end{array}$ \\
\hline $\begin{array}{l}\text { Weiner et al. } \\
2006[24]\end{array}$ & IES & $77 \%$ of cohort displayed psychological distress \\
\hline $\begin{array}{l}\text { Paredes et al. } \\
2011[27]\end{array}$ & BSI & HADS \\
\hline
\end{tabular}

employment status in survivors of sarcoma failed to consider the unemployment rate in the general population during the timeframe of the study. Other studies on employment could usefully investigate the obstacles to finding gainful employment following surgery for extremity sarcoma. For example, pain has been determined to be a major limiting factor in obtaining gainful employment [23]. This may reflect that being occupied is a good distraction for pain, or that pain is a significantly limiting factor for engaging in work-related activities. Nevertheless, it highlights the importance of good pain management, with a multidisciplinary, multimodal approach to pain management. Apart from work, further longitudinal research into change from baseline sport and recreational activity participation, including level of participation, is important concerning determinants of QoL.

Personality facets influence perception of health and QoL. Cognitive interpretations of the locus of control are influenced by the diagnosis of cancer, which interacts with personality factors, socioeconomic status, depression, and anxiety [31]. Few studies had investigated the role of personality in influencing outcomes in extremity sarcoma patients.

Our review identified that there is a significant prevalence of psychological distress in extremity sarcoma survivors. However, few studies have attempted specifically to correlate psychological distress with QoL.

Compared to the normal population, people with chronic disease and cancer such as sarcoma frequently interact with healthcare professionals as part of their followup. These sessions present opportunities for screening, detection and management of psychological distress. Certain groups may be at risk of psychological distress that are not detected and "fall through the gaps" and, hence, not be managed effectively. This may account for the near equal prevalence of current psychological distress symptoms in sarcoma patients and the normal population where overt depression and anxiety are detected and managed. No study reported the incidence of treated psychological distress premorbidly or during treatment for the sarcoma. Paredes et al.s [27] finding that the prevalence of psychological distress wanes with time highlights the need for longitudinal research to determine protective factors that enhance resilience in sarcoma patients. Psychological distress has not been thoroughly investigated but appears to have an important but poorly defined effect on outcomes in patients treated surgically for their sarcoma. Apart from directly affecting QoL, psychological distress may jeopardise management through negative health behaviours, poor decision-making processes, and ineffective rehabilitation to regain optimal mobility. Psychological distress is a modifiable factor through recognition and effective management strategies. Further research into the detection and management of mental health needs of patients with sarcoma is thus important to improve overall outcomes.

There is no gold standard measure of QoL for extremity sarcoma. The MSTS87, MSTS 93, and TESS assess for subjective physical function and objective functional impairment only and does not consider other aspects of QoL that of emotional and social domains. The SF-36 was most commonly used to assess QoL. It consists of eight equally weighted scales of QoL assessment. It is a generic subjective QoL tool that does not take into consideration the unique considerations that are relevant to the extremity sarcoma cohort [32]. For example, it may not take into account the implications of sarcoma as cancer, which may have implications on a threat to life and symptoms of therapy (such as nausea and vomiting during chemotherapy). The EORTC QLQ C-30 may also be inappropriate for use in extremity sarcoma as high scores during nontreatment times may be elevated as it assesses symptoms such as nausea, vomiting, and change in bowel habits. However, it assesses financial difficulties, which may be relevant to the extremity sarcoma cohort, given that patients may experience adverse influences with regards to career opportunities.

From our review, we found that different variable differentially influenced QoL. We found that pain, activity restriction, and a perception that the cancer negatively influenced opportunities were associated with poor QoL.

There is, thus, a need to identify the most discriminatory determinants of QoL in extremity sarcoma patients to develop an extremity sarcoma specific QoL tool for accurate measurement of QoL in this unique cohort. Such a tool will have clinical application in the standardisation of clinical research that compares different treatment modalities.

\section{Conclusion}

Advancements in technology has revolutionised the management of sarcoma and markedly improved the mortality and morbidity of sarcoma. This paper has identified directions for future research, the need for the development of an extremity-sarcoma specific and age appropriate QoL tool, and assessment of modulating biological, psychological, and social factors that influence coping. We propose that a longitudinal, prospective design would best fit these research 


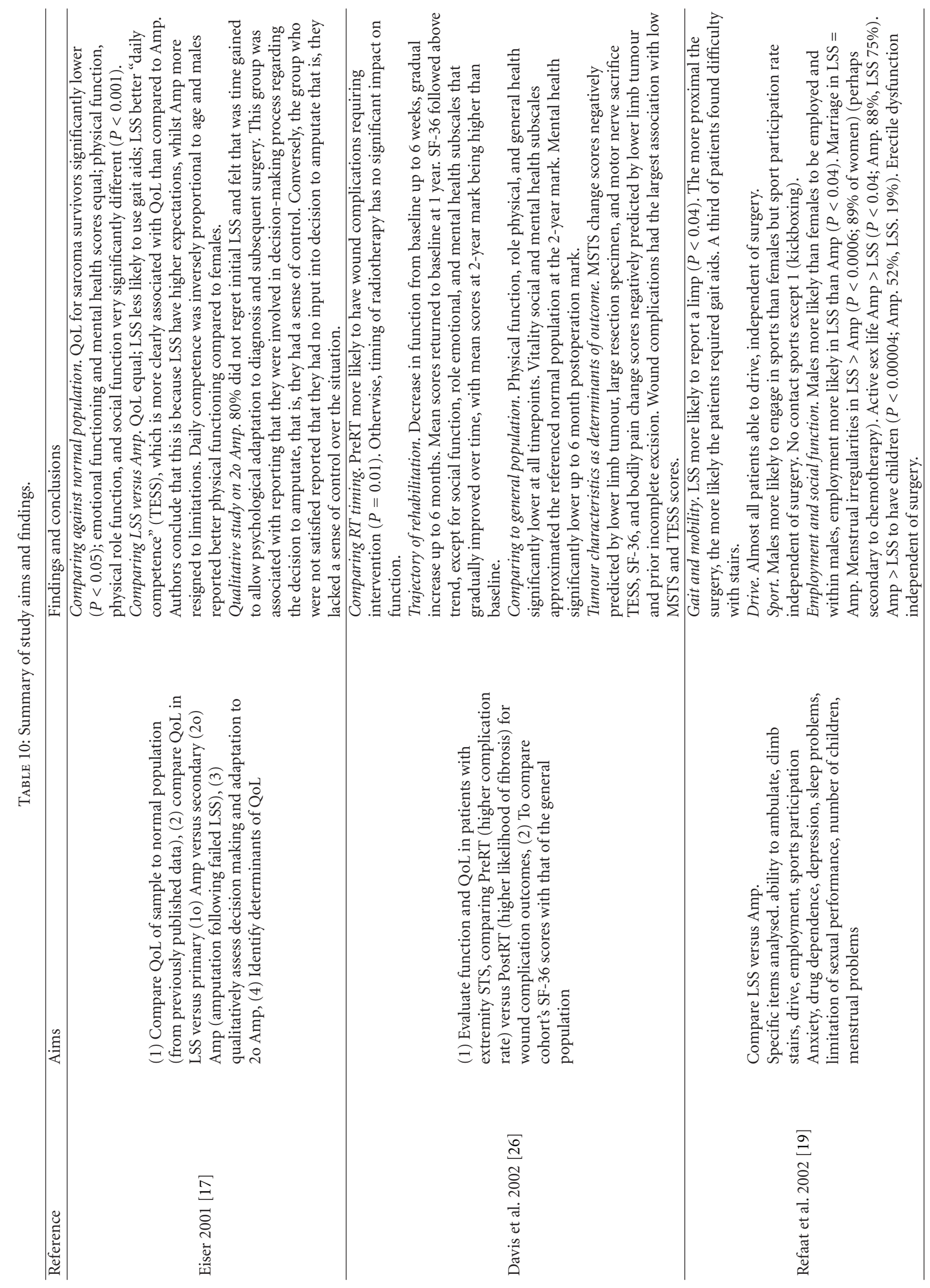




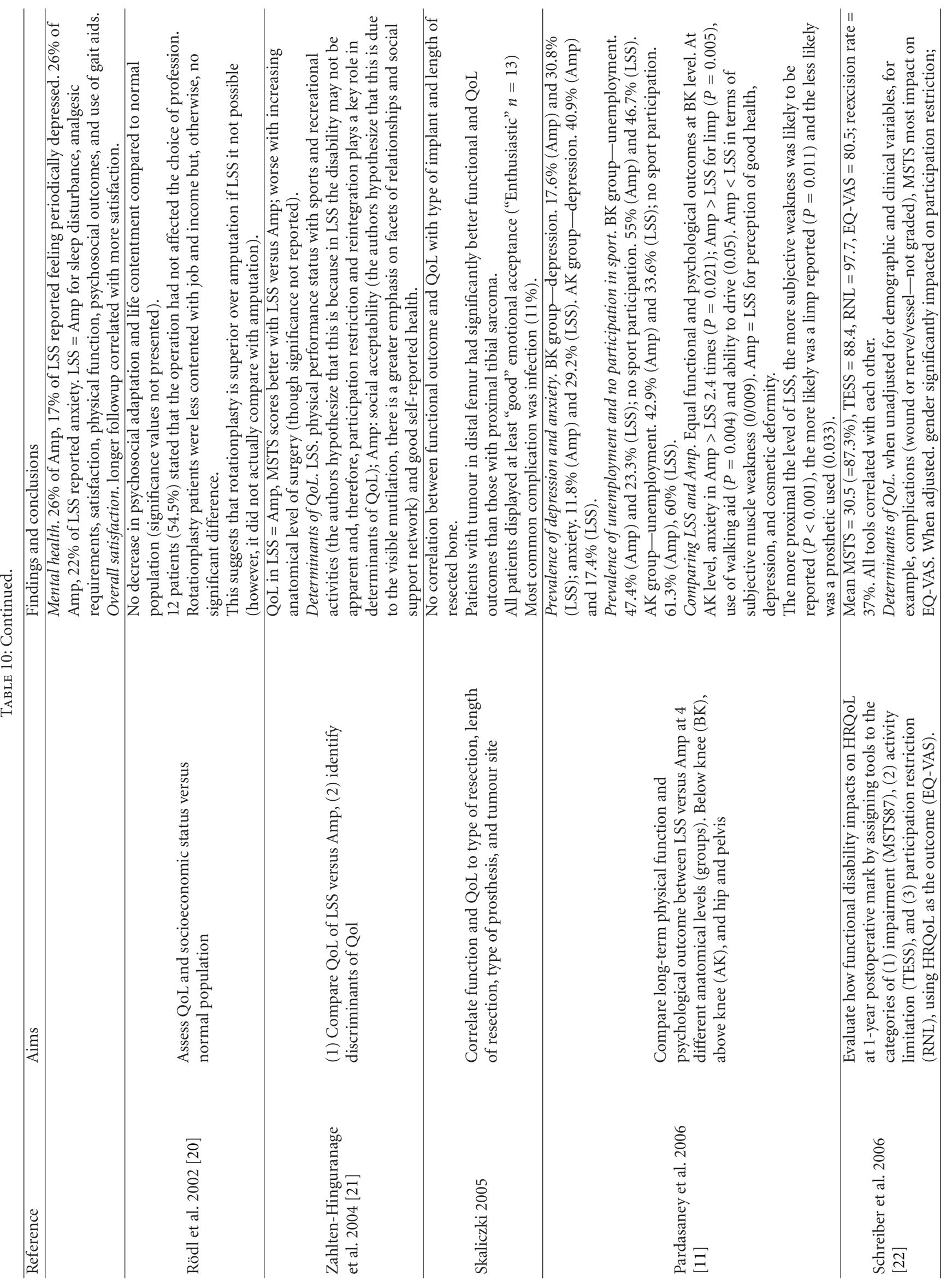




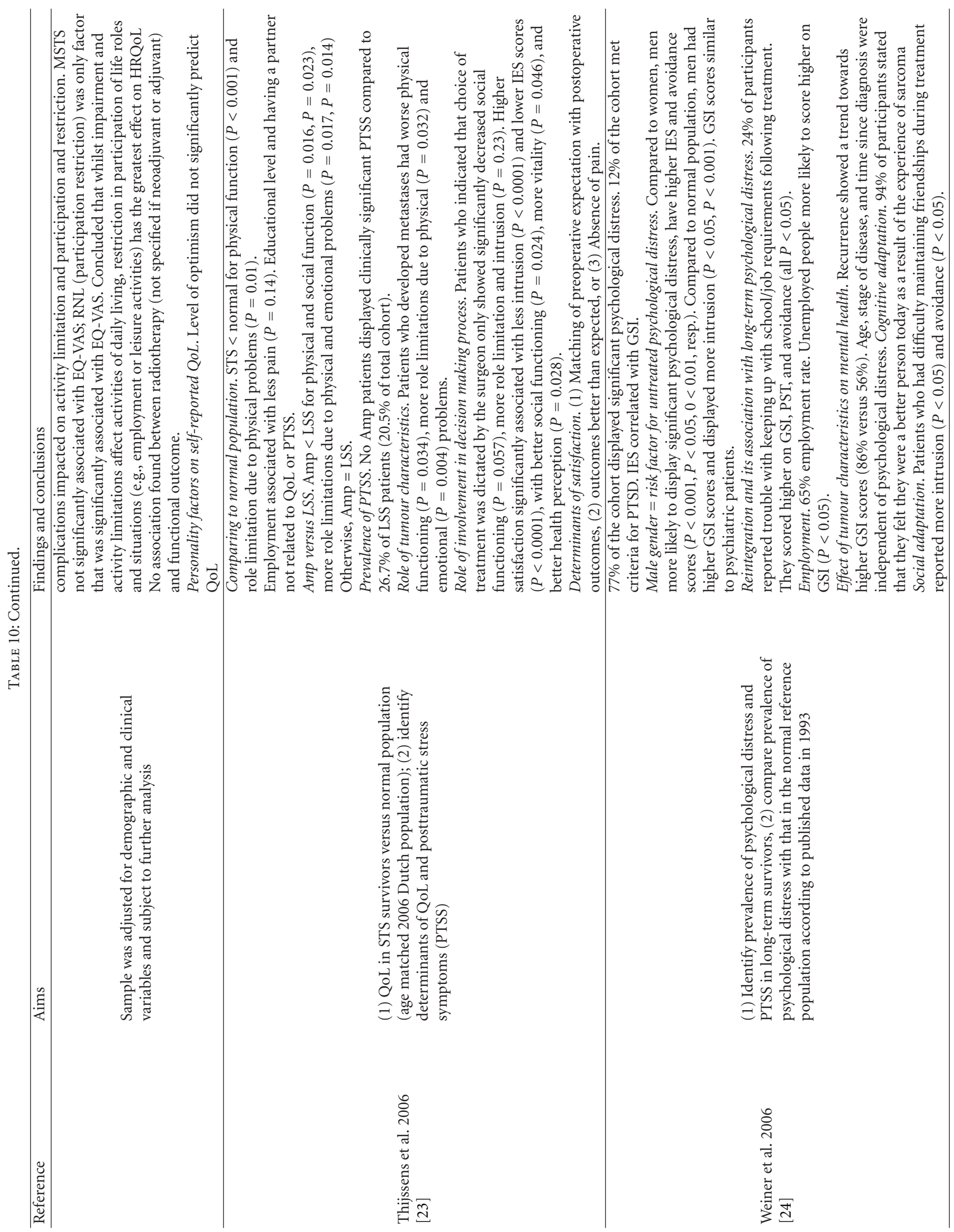




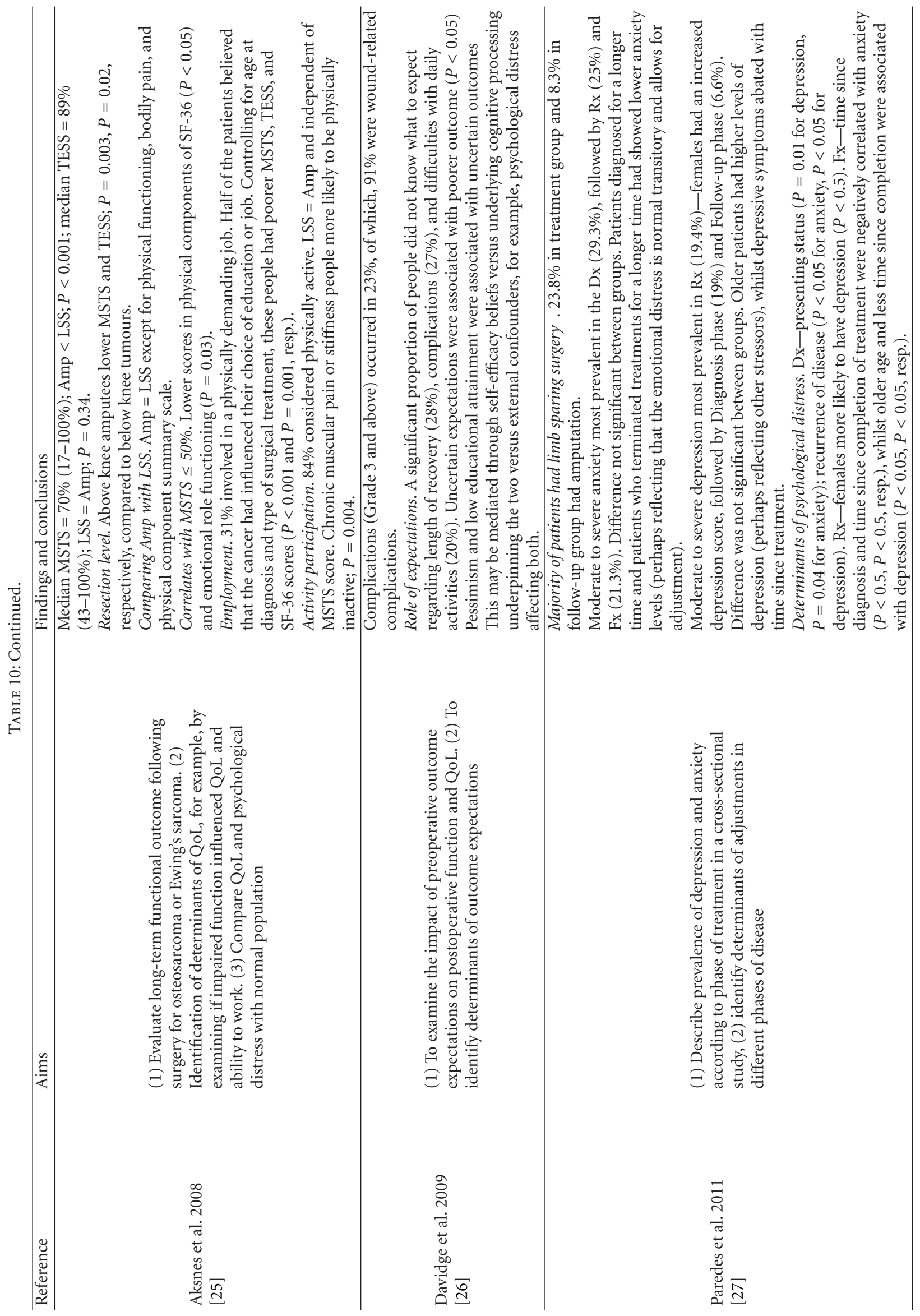


needs. There is also emerging evidence to suggest that psychological distress is an important but often overlooked aspect of care. This justifies further research into the assessment of the role of psychological distress in influencing overall outcomes following surgery for extremity sarcoma. We feel that interventional strategies, such as mindfulness training to reduce the level of psychological distress to enhance QoL outcomes following sarcoma surgery, are a worthwhile endeavour, given its promise in other cancers [33].

\section{Conflict of Interests}

Each author certifies that he or she has no commercial associations that might pose a conflict of interests in connection with the submitted paper.

\section{References}

[1] AIHW Australian Institute of Health and Welfare, "Cancer in Australia: an overview," Canberra, Contract no.: CAN 42, 2008.

[2] B. A. Morrison, "Soft tissue sarcomas of the extremities," Proceedings (Baylor University Medical Center), vol. 16, no. 3, pp. 285-290, 2003.

[3] A. M. Geiger and S. M. Castellino, "Delineating the age ranges used to define adolescents and young adults," Journal of Clinical Oncology, vol. 29, no. 16, pp. e492-e493, 2011.

[4] AIHW Australian Institute of Health and Welfare, "Cancer in Adolescents and Young Adults in Australia," Canberra: AIHW, 2011.

[5] S. Palmer, Ed., "Improving care for AYA patients treated within adult hospitals: what can be done right now?" Cancer Forum, vol. 33, no. 1, pp. 22-25, 2009.

[6] W. F. Enneking, W. Dunham, M. C. Gebhardt, M. Malawar, and D. J. Pritchard, "A system for the functional evaluation of reconstructive procedures after surgical treatment of tumors of the musculoskeletal system," Clinical Orthopaedics and Related Research, no. 286, pp. 241-246, 1993.

[7] N. J. Lindner, O. Ramm, A. Hillmann et al., "Limb salvage and outcome of osteosarcoma: the University of Muenster experience," Clinical Orthopaedics and Related Research, no. 358, pp. 83-89, 1999.

[8] R. Nagarajan, J. P. Neglia, D. R. Clohisy, and L. L. Robison, "Limb salvage and amputation in survivors of pediatric lowerextremity bone tumors: what are the long-term implications?" Journal of Clinical Oncology, vol. 20, no. 22, pp. 4493-4501, 2002.

[9] R. E. Turcotte, M. Ferrone, M. H. Isler, and C. Wong, "Outcomes in patients with popliteal sarcomas," Canadian Journal of Surgery, vol. 52, no. 1, pp. 51-55, 2009.

[10] E. H. C. Wright, S. Gwilym, C. L. M. H. Gibbons, P. Critchley, and H. P. Giele, "Functional and oncological outcomes after limb-salvage surgery for primary sarcomas of the upper limb," Journal of Plastic, Reconstructive and Aesthetic Surgery, vol. 61, no. 4, pp. 382-387, 2008.

[11] P. K. Pardasaney, P. E. Sullivan, L. G. Portney, and H. J. Mankin, "Advantage of limb salvage over amputation for proximal lower extremity tumors," Clinical Orthopaedics and Related Research, no. 444, pp. 201-208, 2006.
[12] R. D. Barr and J. S. Wunder, "Bone and soft tissue sarcomas are often curable_-but at what cost?” Cancer, vol. 115, no. 18, pp. 4046-4054, 2009.

[13] B. S. Langenhoff, P. F. M. Krabbe, T. Wobbes, and T. J. M. Ruers, "Quality of life as an outcome measure in surgical oncology," British Journal of Surgery, vol. 88, no. 5, pp. 643652, 2001.

[14] L. H. Aksnes, K. S. Hall, G. Folleraas et al., "Management of high-grade bone sarcomas over two decades: the Norwegian Radium Hospital experience," Acta Oncologica, vol. 45, no. 1, pp. 38-46, 2006.

[15] A. Gronchi, R. Miceli, C. Colombo et al., "Primary extremity soft tissue sarcomas: outcome improvement over time at a single institution," Annals of Oncology, vol. 22, no. 7, pp. 16751681, 2011.

[16] E. L. Spurrell, C. Fisher, J. M. Thomas, and I. R. Judson, "Prognostic factors in advanced synovial sarcoma: an analysis of 104 patients treated at the Royal Marsden Hospital," Annals of Oncology, vol. 16, no. 3, pp. 437-444, 2005.

[17] C. Eiser, A. S. E. Darlington, C. B. Stride, and R. Grimer, "Quality of life implications as a consequence of surgery: limb salvage, primary and secondary amputation," Sarcoma, vol. 5, no. 4, pp. 189-196, 2001.

[18] A. M. Davis, B. O'Sullivan, R. S. Bell et al., "Function and health status outcomes in a randomized trial comparing preoperative and postoperative radiotherapy in extremity soft tissue sarcoma," Journal of Clinical Oncology, vol. 20, no. 22, pp. 4472-4477, 2002.

[19] Y. Refaat, J. Gunnoe, F. J. Hornicek, and H. J. Mankin, "Comparison of quality of life after amputation or limb salvage," Clinical Orthopaedics and Related Research, no. 397, pp. 298-305, 2002.

[20] R. W. Rödl, U. Pohlmann, G. Gosheger, N. J. Lindner, and W. Winkelmann, "Rotationplasty-quality of life after 10 years in 22 patients," Acta Orthopaedica Scandinavica, vol. 73, no. 1, pp. 85-88, 2002.

[21] A. Zahlten-Hinguranage, L. Bernd, V. Ewerbeck, and D. Sabo, "Equal quality of life after limb-sparing or ablative surgery for lower extremity sarcomas," British Journal of Cancer, vol. 91, no. 6, pp. 1012-1014, 2004.

[22] D. Schreiber, R. S. Bell, J. S. Wunder et al., "Evaluating function and health related quality of life in patients treated for extremity soft tissue sarcoma," Quality of Life Research, vol. 15, no. 9, pp. 1439-1446, 2006.

[23] K. M. J. Thijssens, J. E. H. M. Hoekstra-Weebers, R. J. van Ginkel, and H. J. Hoekstra, "Quality of life after hyperthermic isolated limb perfusion for locally advanced extremity soft tissue sarcoma," Annals of Surgical Oncology, vol. 13, no. 6, pp. 864-871, 2006.

[24] L. Weiner, H. Battles, D. Bernstein et al., "Persistent psychological distress in long-term survivors of peditric sarcoma: the experience at a single institution," Psycho-Oncology, vol. 15, no. 10, pp. 898-910, 2006.

[25] L. H. Aksnes, H. C. F. Bauer, N. L. Jebsen et al., "Limb-sparing surgery preserves more function than amputation," Journal of Bone and Joint Surgery — Series B, vol. 90, no. 6, pp. 786-794, 2008.

[26] K. Davidge, R. Bell, P. Ferguson, R. Turcotte, J. Wunder, and A. M. Davis, "Patient expectations for surgical outcome in extremity soft tissue sarcoma," Journal of Surgical Oncology, vol. 100, no. 5, pp. 375-381, 2009.

[27] T. Paredes, M. C. Canavarro, and M. R. Simões, "Anxiety and depression in sarcoma patients: emotional adjustment and 
its determinants in the different phases of disease," European Journal of Oncology Nursing, vol. 15, no. 1, pp. 73-79, 2011.

[28] G. Wells, B. Shea, D. O'connell, J. Peterson, V. Welch, M. Losos et al., The Newcastle-Ottawa Scale (NOS) for Assessing the Quality of Nonrandomised Studies in Meta-Aanalyses, 2000.

[29] M. A. G. Sprangers and C. E. Schwartz, "Integrating response shift into health-related quality of life research: a theoretical model," Social Science and Medicine, vol. 48, no. 11, pp. 15071515, 1999.

[30] ABS Australian Bureau of Statistics, "National Survey of Mental Health and Wellbeing: Summary of Results 2007," cat. no. 4326.0. Canberra, 2008.

[31] M. J. Naus, E. C. Price, and M. P. Peter, "The moderating effects of anxiety and breast cancer locus of control on depression," Journal of Health Psychology, vol. 10, no. 5, pp. 687-694, 2005.

[32] P. Ruggieri, A. F. Mavrogenis, and M. Mercuri, "Quality of life following limb-salvage surgery for bone sarcomas," Expert Review of Pharmacoeconomics and Outcomes Research, vol. 11, no. 1, pp. 59-73, 2011.

[33] B. Rehse and R. Pukrop, "Effects of psychosocial interventions on quality of life in adult cancer patients: meta analysis of 37 published controlled outcome studies," Patient Education and Counseling, vol. 50, no. 2, pp. 179-186, 2003. 


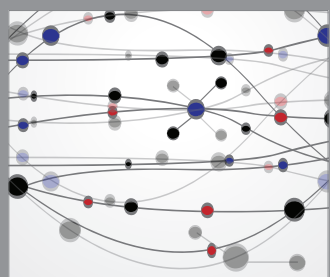

The Scientific World Journal
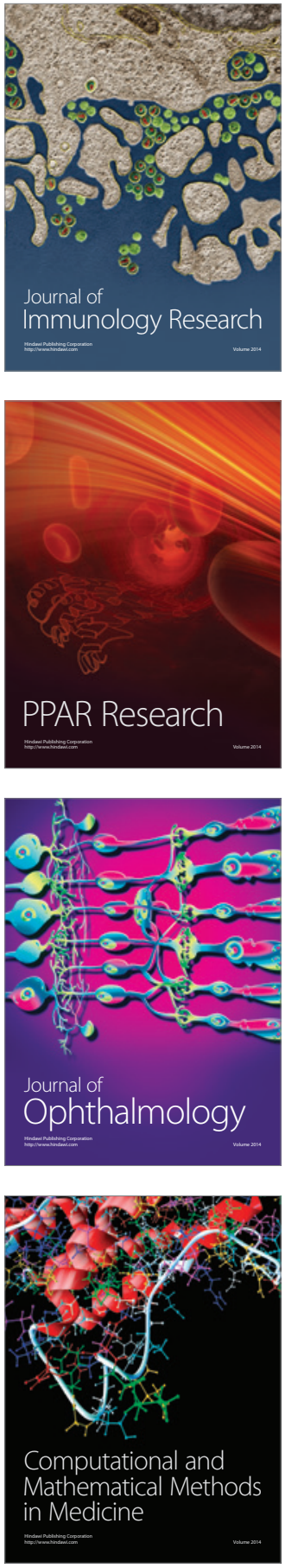

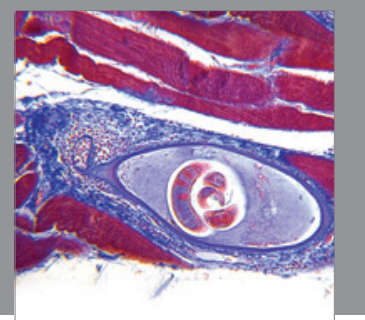

Gastroenterology

Research and Practice
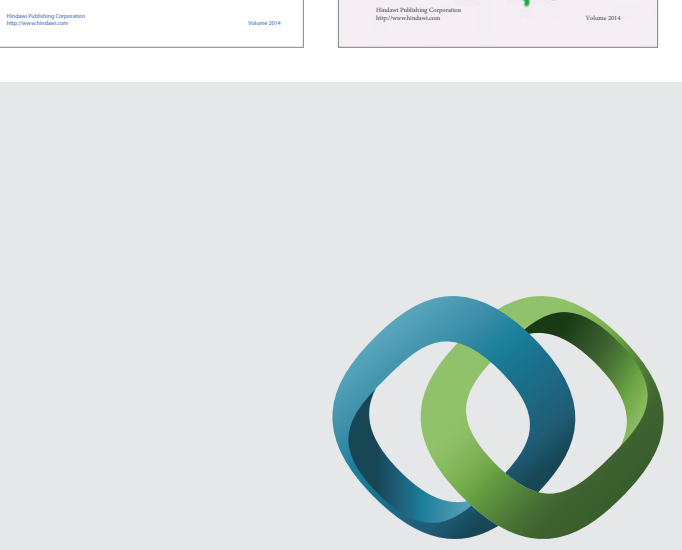

\section{Hindawi}

Submit your manuscripts at

http://www.hindawi.com
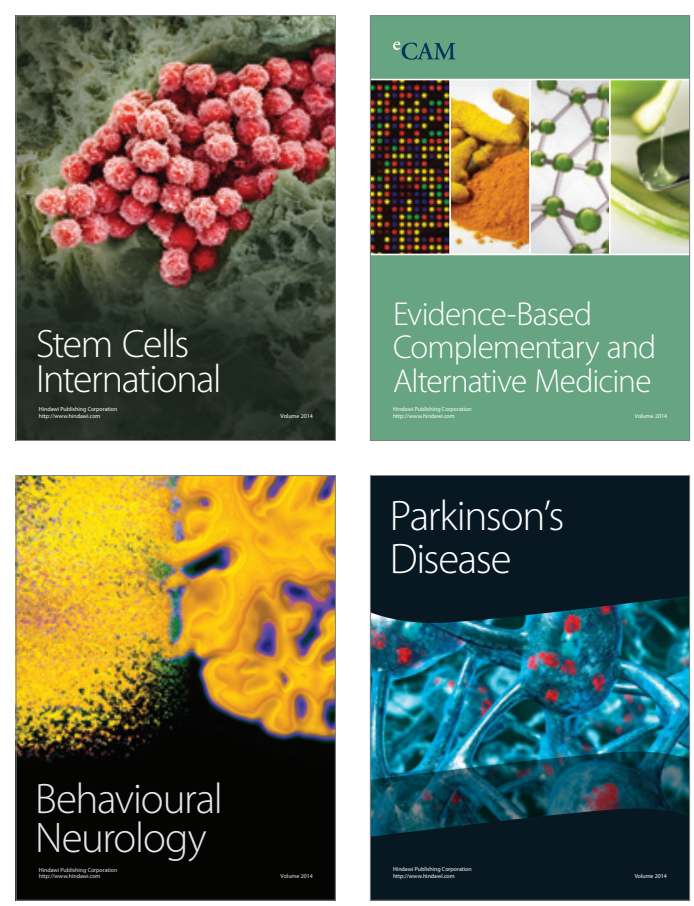

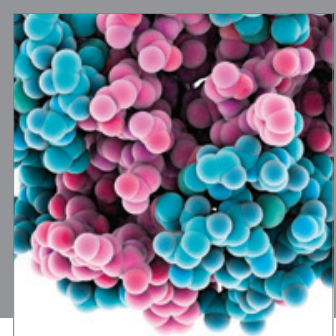

Journal of
Diabetes Research

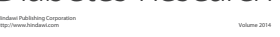

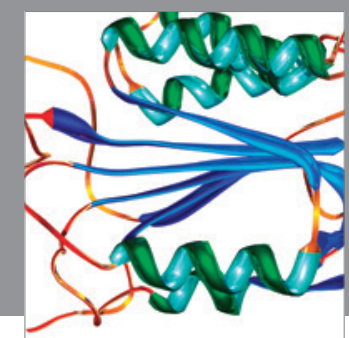

Disease Markers
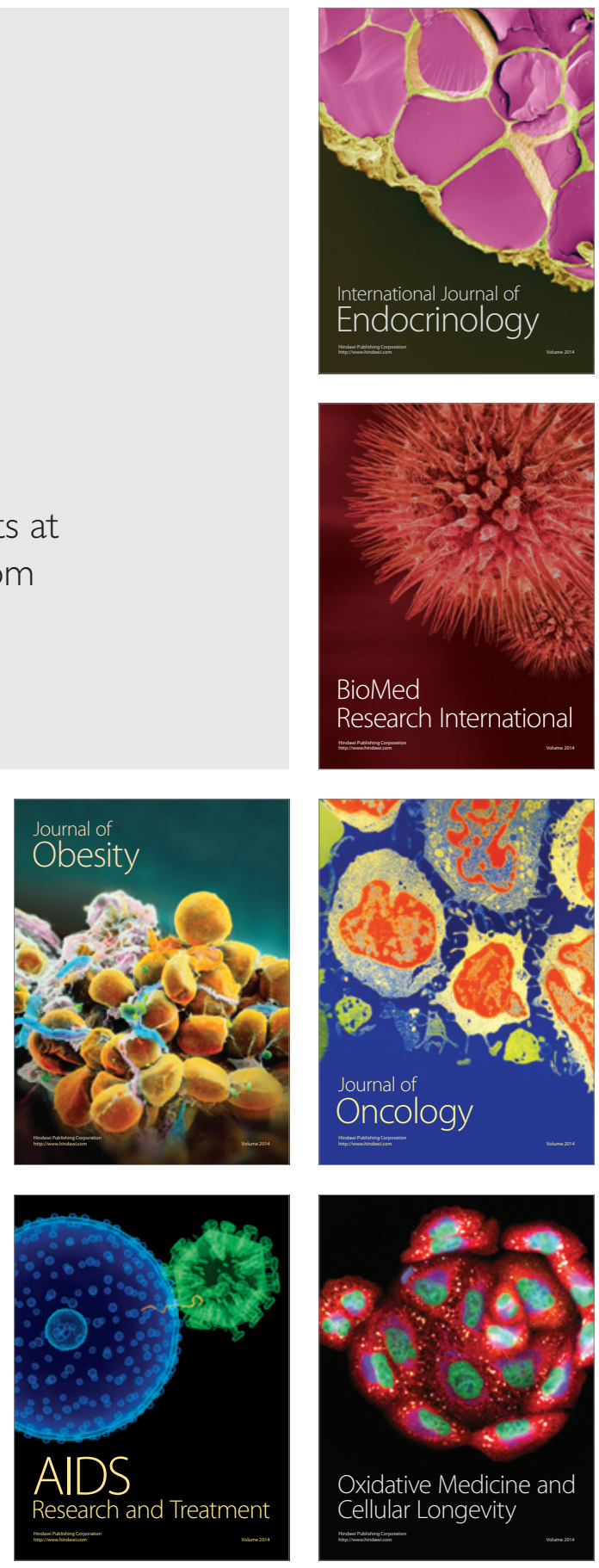